\title{
High frequency of Plasmodium falciparum chloroquine resistance marker (pfcrt T76 mutation) in Yemen: An urgent need to re-examine malaria drug policy
}

Abdulsalam M Al-Mekhlafi ${ }^{*}$, Mohammed AK Mahdy ${ }^{1,2}$, Hesham M Al-Mekhlafi ${ }^{1,2}$, Ahmed A Azazy ${ }^{2}$ and Mun Yik Fong ${ }^{1}$

\begin{abstract}
Background: Malaria remains a significant health problem in Yemen with Plasmodium falciparum being the predominant species which is responsible for $90 \%$ of the malaria cases. Despite serious concerns regarding increasing drug resistance, chloroquine is still used for the prevention and treatment of malaria in Yemen. This study was carried out to determine the prevalence of choloroquine resistance (CQR) of $P$. falciparum isolated from Yemen based on the pfcrt T76 mutation.
\end{abstract}

Methods: A cross-sectional study was carried out among 511 participants from four governorates in Yemen. Blood samples were screened using microscopic and species-specific nested PCR based on the 185 rRNA gene to detect and identify Plasmodium species. Blood samples positive for P. falciparum were used for detecting the pfcrt T76 mutation using nested-PCR.

Results: The prevalence of pfcrt T76 mutation was $81.5 \%$ (66 of 81 isolates). Coastal areas/foothills had higher prevalence of pfcrt T76 mutation compared to highland areas (90.5\% vs 71.8\%) ( $p=0.031)$. The pfcrt T76 mutation had a significant association with parasitaemia $(p=0.045)$. Univariate analysis shows a significant association of pfcrt T76 mutation with people aged $>10$ years $(\mathrm{OR}=9,95 \% \mathrm{Cl}=2.3-36.2, \mathrm{p}=0.001)$, low household income $(\mathrm{OR}=5,95 \% \mathrm{Cl}=1.3-19.5, \mathrm{p}=0.027)$, no insecticide spray $(\mathrm{OR}=3.7,95 \% \mathrm{Cl}=1.16-11.86, \mathrm{p}=0.025)$ and not sleeping under insecticide treated nets (ITNs) $(\mathrm{OR}=4.8,95 \% \mathrm{Cl}=1.38-16.78, \mathrm{p}=0.01)$. Logistic regression model confirmed age $>10$ years and low household income as predictors of pfcrt T76 mutation in Yemen $P$. falciparum isolates.

Conclusions: The high prevalence of pfcrt T76 mutation in Yemen could be a predictive marker for the prevalence of $P$. falciparum CQR. This finding shows the necessity for an in-vivo therapeutic efficacy test for CQ. P. falciparum $\mathrm{CQR}$ should be addressed in the national strategy to control malaria.

\section{Background}

Malaria remains the major cause of disease and death in the world, especially among children and pregnant women [1-4]. Malaria treatment depends on the type and severity of the disease. Chloroquine (CQ) is safe, inexpensive, and used for the treatment of uncomplicated

\footnotetext{
* Correspondence: halkasemi@yahoo.com

'Department of Parasitology, Faculty of Medicine, University of Malaya,

50603 Kuala Lumpur, Malaysia

Full list of author information is available at the end of the article
}

malaria [5]. However, since the early 1960s, resistance of $P$. falciparum to chloroquine has been rising [6-10]. The P. falciparum CQ resistance transporter ( $p f c r t)$ T76 mutation is the most important molecular marker [11-18]. This point of mutation has shown strong correlation with in vivo and in vitro $C Q$ resistance making pfcrt T76 mutation a significant marker for the prediction of the spread of $P$. falciparum CQ resistance $[7,16,17,19-23]$

\section{Ciomed Central}

(C) 2011 Al-Mekhlafi et al; licensee BioMed Central Ltd. This is an Open Access article distributed under the terms of the Creative Commons Attribution License (http://creativecommons.org/licenses/by/2.0), which permits unrestricted use, distribution, and reproduction in any medium, provided the original work is properly cited. 
In Yemen, where $60 \%$ of the total population live in malarious areas, the disease remains a significant health problem but chloroquine is still used [10,24]. Three Plasmodium species (P. falciparum, $P$. vivax and $P$. malariae) are reported in Yemen with $P$. falciparum being the predominant species [24-29]. The CQR problem is constantly growing since the detection of the first indigenous cases of P. falciparum CQR in 1989 [24]. Over the past two decades, few studies have been carried out to examine antimalarial drug efficacies in Yemen, both in vivo and in vitro $[24,25,30]$. However, no information about antimalarial drug resistance is available from highland areas which are endemic for malaria in Yemen. This study is the first study which aims to determine the prevalence of $p f c r t 76 \mathrm{~T}$ mutation among patients with $P$. falciparum in Yemen and to compare the prevalence of $p f c r t 76 \mathrm{~T}$ mutation between highland and coastal areas/foothills.

\section{Materials and methods}

\section{Study areas and population}

The present study was conducted in four governorates of Yemen (Figure 1). Taiz and Hodeidah represent the mountainous hinterland and coastal areas, respectively. Rymah and Dhamar represent the highland areas. The peak time of malaria transmission in the coastal areas occurs in winter (October-April), while in the western mountains, the peak occurs in the summer (May-
September). In the highlands areas (> 2000 metres above sea level), the transmission of malaria occurs throughout the year [31]. Anopheles arabiensis is the main vector in the country but $A$. culicifacies plays an important role in the transmission of malaria in the coastal areas. A. sergenti has also been reported in the mountainous hinterland and highland areas [31]. In the western costal area, temperatures are very high and occasionally exceed $54^{\circ} \mathrm{C}$ with irregular heavy torrents of rainfall. The mountainous hinterland receives from about 1,000-1,500 millimetres of rain each year with mild temperature in summer and cold in the winter with average temperature of $21^{\circ} \mathrm{C}$. The climate in the highlands is characterized by a temperate, rainy summer with an average temperature of $20^{\circ} \mathrm{C}$. The minimum sample size required for this study (246 subjects) was calculated based on previous prevalence reported in Yemen with 5\% significance level and confidence level of $95 \%[24,27,32]$.

\section{Data collection}

A total of 511 blood samples were collected between June 2008 and March 2009. Blood samples were collected through finger pricks from febrile patients attending public and private health centres and hospitals. Thin and thick blood films were prepared and blood drops were spotted on Whatman filter papers 3 MM (Whatman International Ltd., Maidstone, England).

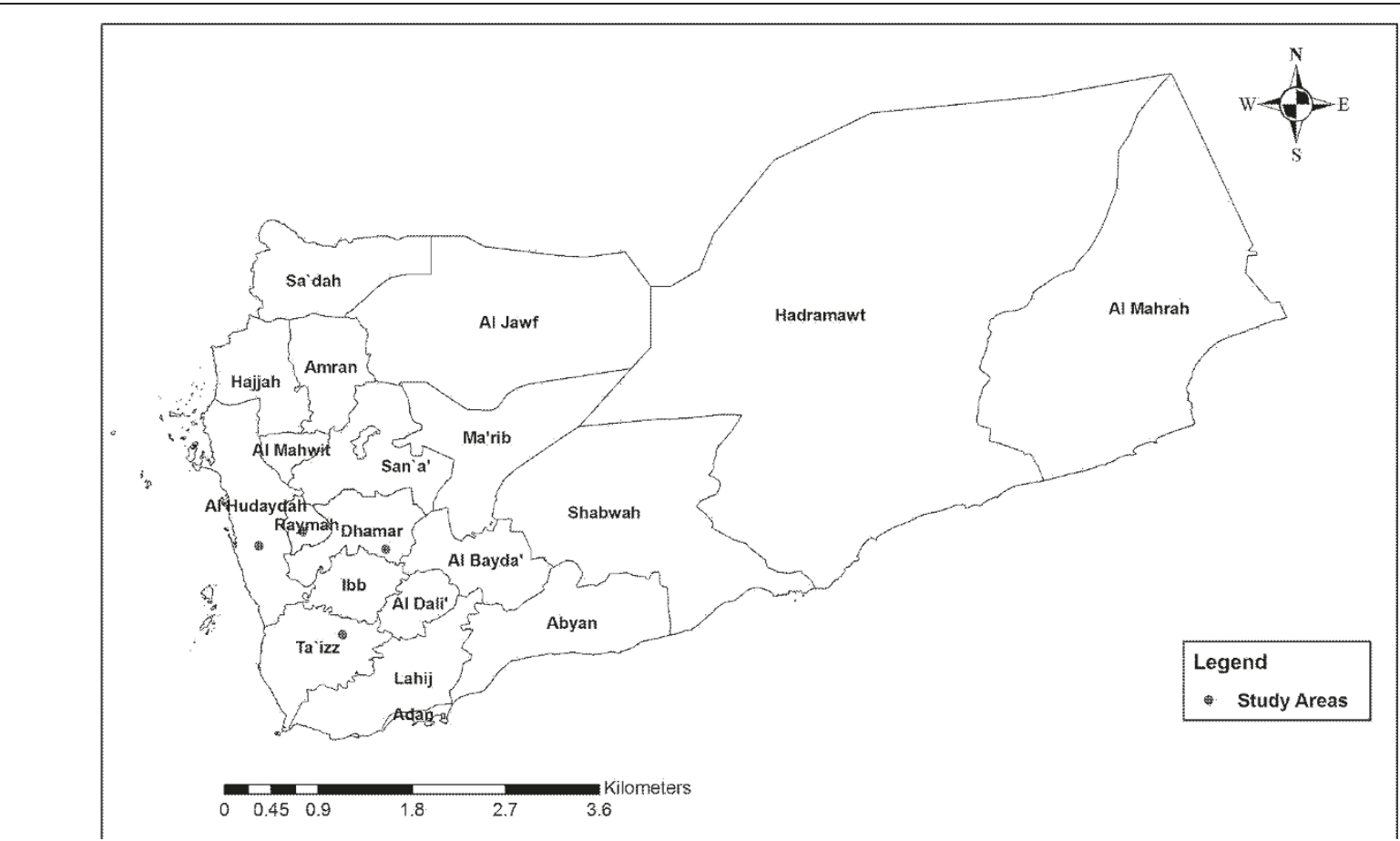

Figure 1 A geographic map shows study area 
Demographic and socioeconomic information of participants were collected using a pre-tested questionnaire.

\section{Microscopic examination}

Thick and thin blood films were prepared, air dried and stained with diluted Giemsa stain (1:20, vol/vol) for $20 \mathrm{~min}$. All slides were examined by local microscopists for malaria parasites. Re-examination and species level identification were performed in a blind manner, in two different laboratories by two expert microscopists following standard and quality-controlled procedures. Parasitaemia levels were obtained from thick smears by counting the number of asexual parasites against 200 leucocytes and expressed per micro liter of blood using an assumed leukocyte count of $8000 \mathrm{wbc} / \mathrm{ul}$.

\section{Molecular identification of Plasmodium species and pfcrt T76 mutation}

Parasite genomic DNA was extracted from the blood collected on filter paper. DNA was extracted using QIAgen DNA Mini Kit for Blood and Tissue (QIAGEN, Germany) according to the manufacturer's instructions. Nested PCR assays based on 18S rRNA gene were used to detect and identify the Plasmodium species as mentioned previously [33]. The detection of the $p f c r t$ T76 mutation was done according to the protocol described previously $[7,34]$. The allele-specific polymerase chain reaction (AS-PCR) was used. Nest 1 was carried out using $250 \mathrm{nM}$ of TCRP1 (5'-CCG TTA ATA ATA AAT ACA CGC AG-3') and TCRP2 (5'CGG ATG TTA CAA AAC TAT AGT TAC C-3') primers in a $25 \mu \mathrm{l}$ reaction mixture containing $1 \mathrm{X}$ PCR buffer (iNtRON), $2.5 \mathrm{mM} \mathrm{MgCl}_{2}$ (iNtRON), $0.2 \mathrm{mM}$ of dNTPs (iNtRON), $1 \mathrm{U}$ of Taq polymerase (iNtRON) and $4 \mu \mathrm{l}$ of extracted DNA. Initial denaturation was carried out for 3 minutes at $94^{\circ} \mathrm{C}$ followed by 30 cycles of denaturing for 30 seconds at $94^{\circ} \mathrm{C}$, annealing for 30 seconds at $56^{\circ} \mathrm{C}$ and extension at $60^{\circ} \mathrm{C}$ for 1 minute. The final extension was carried out at $60^{\circ} \mathrm{C}$ for 3 minutes.

For allele-specific PCR, $2 \mu \mathrm{l}$ of the nest 1 product was used in a volume $25 \mu \mathrm{l}$ reaction containing $1 \mathrm{X}$ PCR buffer (iNtRON), $1.5 \mathrm{mM} \mathrm{MgCl}_{2}$ (iNtRON), $0.2 \mathrm{mM}$ of dNTPs (iNtRON), and $1 \mathrm{U}$ of Taq polymerase (iNtRON). The primer TCRP3 (5'-TGA CGA GCG TTA TAG AG-3') was used with a mutant-specific primer TCRP4 m (5'-GTT CTT TTA GCA AAA ATT G3') or a wild-type-specific primer TCRPw (5'-GTT CTT TTA GCA AAA ATT T-3'). The PCR conditions were performed same as for nest 1 , except that the annealing was $47^{\circ} \mathrm{C}$, extension was $64^{\circ} \mathrm{C}$ and the number of cycles were 25 . The PCR products were resolved by electrophoresis in a $1.5 \%$ agarose gel.

\section{Data analysis}

Data analysis was performed by SPSS version 11.5 (SPSS Inc., Chicago, IL, USA). Chi-square test (or Fisher's exact test when required) was used to test the differences between groups. For univariate analysis, odds ratio and $95 \%$ confidence interval were used. A value of $P<$ 0.05 was considered statistically significant. Those variables that showed significance with $\mathrm{P}<0.05$, were used to develop a stepwise forward logistic regression model.

\section{Ethical approval}

The protocol of this study was approved by Sana'a University, Republic of Yemen and participants with febrile illness who gave written informed consents were included in this study.

\section{Results}

\section{Demographic characteristic}

A total of 511 participants (268 males and 242 females), with a median age of 20 years and interquartile range of 22 years voluntarily participated in this study. The basic characteristics of the participants are shown in Table 1.

Out of 511 blood specimens, malaria parasites were detected in $78(15.3 \%)$ by microscopic examination for the thin and thick blood films as compared to 86 (16.8\%) by nested PCR amplification of the $18 \mathrm{~S}$ rRNA gene. Majority of the malarial infections were due to $P$. falciparum (80.3\%).

\section{Prevalence and distribution}

Of the $81 \mathrm{P}$. falciparum positive samples, pfcrt $76 \mathrm{~T}$ mutation was detected in $66(81.5 \%)$. Wild type was detected in $15(18.5 \%)$ and $10(10.3 \%)$ were mixed (Figure 2). The pfcrt 76T mutation was detected in all governorates where the study was conducted. Prevalence was significantly higher in coastal areas/foothills (90.5\%) as compared to highland areas $(71.8 \%)\left(\chi^{2}=4.67, \mathrm{P}=\right.$ 0.031). There was a significant association between $p f c r t$ $76 \mathrm{~T}$ mutation and parasitaemia (Fisher exact test, $\mathrm{P}=$ 0.045) (Figure 3).

\section{Univariate and multivariate analysis}

The associations of the prevalence of pfcrt 76T mutations with the potential risk factors are presented in Table 2. The pfcrt $76 \mathrm{~T}$ mutation was significantly associated with age group $>10$ years $(\mathrm{OR}=9.2,95 \%$ $\mathrm{CI}=2.3-36.2, \mathrm{P}=0.001)$, low household income (OR $=5.0,95 \% \mathrm{CI}=1.3-19.5, \mathrm{P}=0.027)$, not spraying insecticides $(\mathrm{OR}=3.7,95 \% \mathrm{CI}=1.16-11.86, \mathrm{P}=$ $0.025)$ and not using ITNs (OR $=4.8,95 \% \mathrm{CI}=1.38$ $16.78, \mathrm{P}=0.01$ ). By using logistic regression analysis, the age group $>10$ years and low household income were retained as significant factors associated with pfcrt 76T mutations. 
Table 1 Characteristic of study population

\begin{tabular}{|c|c|c|}
\hline Variable & $\mathrm{n}$ & $\%$ \\
\hline \multicolumn{3}{|l|}{ Age (years) } \\
\hline$\leq 10$ & 147 & 29 \\
\hline$>10$ & 364 & 71 \\
\hline \multicolumn{3}{|l|}{ Sex } \\
\hline Male & 268 & 47 \\
\hline Female & 241 & 53 \\
\hline \multicolumn{3}{|l|}{ Residence } \\
\hline Rural & 275 & 54 \\
\hline Urban & 234 & 46 \\
\hline \multicolumn{3}{|l|}{ Household income } \\
\hline High ( $\geq 100$ US dollars/month) & 187 & 37 \\
\hline Low (< 100 US dollars/month) & 322 & 63 \\
\hline \multicolumn{3}{|l|}{ Quality of housing* } \\
\hline Good & 456 & 90 \\
\hline Bad & 52 & 10 \\
\hline \multicolumn{3}{|l|}{ Clothes } \\
\hline Long (covering arms and legs) & 298 & 59 \\
\hline Short & 208 & 41 \\
\hline \multicolumn{3}{|l|}{ Insecticide spray } \\
\hline Yes & 152 & 30 \\
\hline No & 353 & 70 \\
\hline \multicolumn{3}{|l|}{ Using ITNs } \\
\hline Yes & 152 & 30 \\
\hline No & 356 & 70 \\
\hline \multicolumn{3}{|l|}{ Water stream ( $\leq 200 \mathrm{~m}$ of household) } \\
\hline Yes & 167 & 33 \\
\hline No & 340 & 67 \\
\hline \multicolumn{3}{|l|}{ Closing house windows } \\
\hline Yes & 327 & 64 \\
\hline No & 181 & 36 \\
\hline
\end{tabular}

n: number of subjects

*Good housing condition was defined as being complete, made up of stones/ bricks with no opening or holes. Bad housing condition did not have all these characteristics

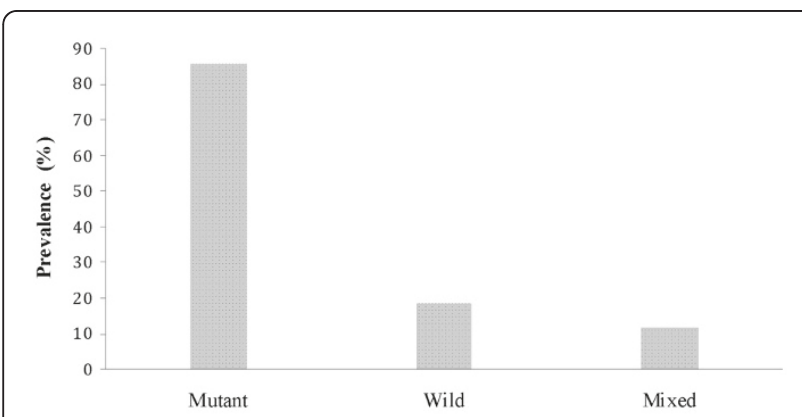

Figure 2 Prevalence of pfcrt T76 mutation in Plasmodium falciparum Yemen isolates.

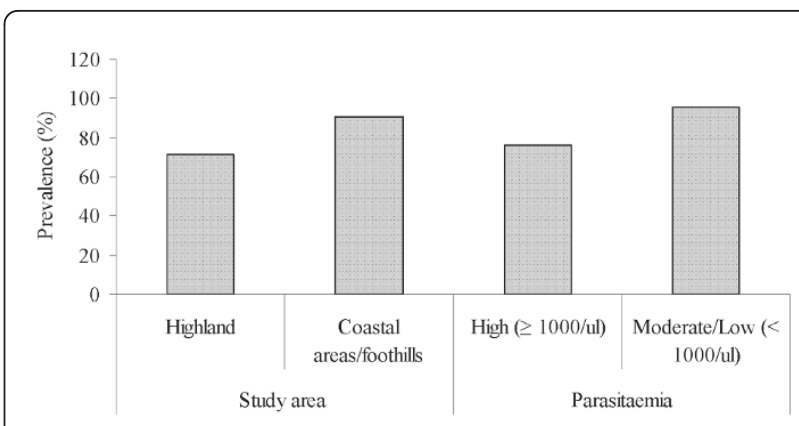

Figure 3 Prevalence of pfcrt T76 mutation in Plasmodium falciparum Yemen isolates in different endemic areas and according to parasitaemia.

\section{Discussion}

Malaria is an endemic disease in Yemen which causes thousands of deaths per year and almost two-thirds of the people are at risk of acquiring the disease. Yemen has not achieved significant decrease in the annual number of malaria cases as compared to other countries in the region such as Iraq, Iran and Saudi Arabia which have entered the malaria elimination or pre-elimination stage [10]. P. falciparum is the predominant species in Yemen, accounted for about $90 \%$ of malaria cases $[24,25,27,28,31,35]$. This study depends on the detection of a single point mutation in codon $76 \mathrm{~T}$ of the $p f c r t$ gene, which has shown a strong and significant association with in vitro and in vivo susceptibility to chloroquine [11-18].

The study showed high prevalence of pfcrt 76T mutation in Yemen with coastal areas/foothills having higher rate as compared to highland areas. This finding is consistent with previous in vivo and in vitro studies carried out in coastal areas/foothills [24,30]. In Hodeidah (coastland areas), in vivo study found CQR in $71 \%$ of $P$. falciparum-infected patients[25]. In in vitro study, carried out in the same area using mark III technique, reported $47 \%$ of CQR [30]. CQR was also reported from Taiz (foothills areas) using a 7-day in vivo test [24]. However, there are no previous reports of CQR from highland areas endemic for malaria in Yemen. The pfcrt $76 \mathrm{~T}$ mutation has been considered as a key determinant of chloroquine treatment failure both in vitro and in the field [11-18]. Thus, the high prevalence of this marker warrants public health awareness on the emergence and spread of $P$. falciparum CQR in Yemen.

The present study found significant association of $p f c r t 76 \mathrm{~T}$ mutation with moderate/low parasitaemia. The relationship between pfcrt $76 \mathrm{~T}$ mutation and malaria severity is a controversial issue. Studies carried 
Table 2 Socio-economic factors associated with pfcrt T76 mutation

\begin{tabular}{|c|c|c|c|c|c|}
\hline Variable & $\begin{array}{l}P . f \\
\mathrm{n}\end{array}$ & $\begin{array}{l}\text { Pfcrt T76 n } \\
\text { (\%) }\end{array}$ & OR & $\begin{array}{c}95 \% \\
\mathrm{Cl}\end{array}$ & $\begin{array}{c}P \\
\text { value }^{\#}\end{array}$ \\
\hline \multicolumn{6}{|l|}{ Age (years) } \\
\hline$\leq 10$ & 32 & $20(63)$ & 9.2 & $\begin{array}{l}2.3- \\
36.2\end{array}$ & $0.001^{\ddagger}$ \\
\hline$>10$ & 49 & $46(94)$ & & & \\
\hline \multicolumn{6}{|l|}{ Sex } \\
\hline Male & 51 & $42(82)$ & 1.16 & $\begin{array}{l}0.37- \\
3.71\end{array}$ & 0.506 \\
\hline Female & 30 & $24(80)$ & & & \\
\hline \multicolumn{6}{|l|}{ Residence } \\
\hline Rural & 66 & $54(82)$ & 1.12 & $\begin{array}{l}0.07- \\
4.6\end{array}$ & 0.56 \\
\hline Urban & 15 & $12(80)$ & & & \\
\hline \multicolumn{6}{|l|}{ Household income } \\
\hline $\begin{array}{l}\text { High ( } \geq 100 \text { US dollars/ } \\
\text { month) }\end{array}$ & 11 & $6(55)$ & 5 & $\begin{array}{l}1.3- \\
19.5\end{array}$ & $0.027^{\ddagger}$ \\
\hline $\begin{array}{l}\text { Low (< } 100 \text { US dollars/ } \\
\text { month) }\end{array}$ & 70 & $60(86)$ & & & \\
\hline \multicolumn{6}{|l|}{ Quality of housing* } \\
\hline Good & 71 & $57(80)$ & 2.21 & $\begin{array}{l}0.25- \\
18.92\end{array}$ & 0.408 \\
\hline Bad & 10 & $9(90)$ & & & \\
\hline \multicolumn{6}{|l|}{ Clothes } \\
\hline $\begin{array}{l}\text { Long (covering arms } \\
\text { and legs) }\end{array}$ & 27 & $24(89)$ & 0.26 & $\begin{array}{l}0.06- \\
1.3\end{array}$ & 0.068 \\
\hline Short & 54 & $42(78)$ & & & \\
\hline \multicolumn{6}{|l|}{ Insecticide spray } \\
\hline Yes & 28 & $19(68)$ & 3.7 & $\begin{array}{l}1.16- \\
11.86\end{array}$ & 0.025 \\
\hline No & 53 & $47(89)$ & & & \\
\hline \multicolumn{6}{|l|}{ Using ITNs } \\
\hline Yes & 35 & $24(69)$ & 4.8 & $\begin{array}{l}1.38- \\
16.78\end{array}$ & 0.01 \\
\hline No & 46 & $42(91)$ & & & \\
\hline \multicolumn{6}{|l|}{$\begin{array}{l}\text { Water stream ( } \leq 200 \mathrm{~m} \text { of } \\
\text { household) }\end{array}$} \\
\hline Yes & 49 & $39(80)$ & 0.72 & $\begin{array}{l}0.22- \\
2.35\end{array}$ & 0.407 \\
\hline No & 32 & $27(84)$ & & & \\
\hline \multicolumn{6}{|l|}{ Closing house windows } \\
\hline Yes & 35 & $28(80)$ & 1.18 & $\begin{array}{l}0.38- \\
3.66\end{array}$ & 0.492 \\
\hline No & 46 & $38(83)$ & & & \\
\hline
\end{tabular}

$\mathrm{n}$ : number of subjects

* Confirmed as a significant risk factor by logistic regression

*Good housing condition was defined as being complete, made up of stones/ bricks with no opening or holes. Bad housing condition did not have all these characteristics.

out in Sudan [36] and Congo [37] showed no significant association between severe malaria and frequency of pfcrt 76T mutation. However, significant association of pfcrt 76T mutation with severity of malaria was reported from India [38] and Mali [21]. The reason for these observations is still unclear [21].

Logistic regression analysis of socio-economic factors indicated a significant association of pfcrt 76T mutation with the age group $>10$ years and low household income. These findings may be explained by the fact that these factors may increase human exposure to mosquito bites leading to high intensity of malaria transmission. Adults, especially in the coastal areas/foothill during the hot season, wear short clothes and may sleep in the courtyard of the house. Low household income plays a significant role in malaria transmission since it affects housing, living place, prevention and treatment [39-41]. The correlation between intensity of malaria transmission and genetic diversity, which may provide a mechanism for the emergence of drug resistance in $P$. falciparum population, has been reported [42].

\section{Conclusions}

Our study reveals high prevalence of $p f c r t 76 \mathrm{~T}$ point mutation in Yemen, suggesting high prevalence and spread of $P$. falciparum CQR. This should be taken into consideration in the national strategy to control malaria. Data from this study support an urgent need to reexamine malaria drug policy. Continuous surveillance to detect emergence of anti-malarial drug resistance is essential in Yemen.

\section{Acknowledgements}

The authors thank Entesar Mansour M.H. and Nemah O. M. Bin Shuaib for their assistance in the laboratory work. Thanks are due to all the technical staff in the hospitals and medical centres in the five governorates especially Ali Al-Hawery, Moath M. Mansour, Sultan Ayesh, Ashraf Saleh and Ahlam AlKobati. We thank Romano Ngau from Department of Parasitology, University of Malaya for creating the map of the study areas. The study was funded by a research grant from the University of Malaya, Kuala Lumpur, Malaysia (Research Code PS175/2008C).

\section{Author details}

${ }^{1}$ Department of Parasitology, Faculty of Medicine, University of Malaya, 50603 Kuala Lumpur, Malaysia. ${ }^{2}$ Department of Parasitology, Faculty of Medicine and Health Sciences, Sana'a University, Sana'a, Yemen.

\section{Authors' contributions}

AMA, MAKM, FMY and AAA designed the study; AMA the field study, carried out the laboratory work and collated the data; AMA, MAKM and HMA performed the statistical analysis; AMA, MAKM, FMY and AAA interpreted the data; AMA and MAKM drafted the manuscript; FMY, AAA, and HMA contributed to the revision of the manuscript. All authors read and approved the final manuscript.

\section{Competing interests}

The authors declare that they have no competing interests.

Received: 18 April 2011 Accepted: 27 May 2011 Published: 27 May 2011

\section{References}

1. Sachs J, Malaney P: The economic and social burden of malaria. Nature 2002, 415:680-685 
2. Hviid L: Adhesion specificities of Plasmodium falciparum-infected erythrocytes involved in the pathogenesis of pregnancy-associated malaria. Am J Pathol 2007, 170:1817-1819.

3. Joubert F, Harrison CM, Koegelenberg RJ, Odendaal CJ, de Beer TA: Discovery: an interactive resource for the rational selection and comparison of putative drug target proteins in malaria. Malar J 2009, $8: 178$

4. Corbel V, Henry MC: Prevention and control of malaria and sleeping sickness in Africa: Where are we and where are we going? Parasit Vectors 2011, 4:37.

5. Ketema T, Getahun K, Bacha K: Therapeutic efficacy of chloroquine for treatment of Plasmodium vivax malaria cases in Halaba district, South Ethiopia. Parasit Vectors 2011, 4:46.

6. Bloland B: Drug resistance in Malaria. Geneva: World Health Organization; 200127, WHO/CDS/DRS/2001-4.

7. Djimde A, Doumbo OK, Cortese JF, Kayentao K, Doumbo S, Diourte $Y$, Dicko A, Su XZ, Nomura T, Fidock DA, et al: A molecular marker for chloroquine-resistant falciparum malaria. N Engl J Med 2001, 344:257-263.

8. Trape JF, Pison G, Spiegel A, Enel C, Rogier C: Combating malaria in Africa. Trends Parasitol 2002, 18:224-230.

9. Mita T, Tanabe K, Kita K: Spread and evolution of Plasmodium falciparum drug resistance. Parasitol Int 2009, 58:201-209.

10. WHO: World Malaria Report. Book World Malaria Report City: World Health Organization; 2009.

11. Ursing J, Kofoed PE, Rodrigues A, Rombo L, Gil JP: Plasmodium falciparum genotypes associated with chloroquine and amodiaquine resistance in Guinea-Bissau. Am J Trop Med Hyg 2007, 76:844-848,

12. Djimde AA, Dolo A, Ouattara A, Diakite S, Plowe CV, Doumbo OK: Molecular diagnosis of resistance to antimalarial drugs during epidemics and in war zones. J Infect Dis 2004, 190:853-855.

13. Djimde A, Doumbo OK, Steketee RW, Plowe CV: Application of a molecular marker for surveillance of chloroquine-resistant falciparum malaria. Lancet 2001, 358:890-891.

14. Lakshmanan V, Bray PG, Verdier-Pinard D, Johnson DJ, Horrocks P Muhle RA, Alakpa GE, Hughes RH, Ward SA, Krogstad DJ, et al: A critical role for PfCRT K76T in Plasmodium falciparum verapamil-reversible chloroquine resistance. EMBO J 2005, 24:2294-2305.

15. Wilson PE, Kazadi W, Kamwendo DD, Mwapasa V, Purfield A, Meshnick SR: Prevalence of pfcrt mutations in Congolese and Malawian Plasmodium falciparum isolates as determined by a new Taqman assay. Acta Trop 2005, 93:97-106.

16. Tagelsir N, Ibrahim Z, Medani A, Salih O, Hamad A, Giha H, El-Agib A, Khan B, Saeed N, Ibrahim M: High frequency of Plasmodium falciparum PfCRT K76T and PfpghN86Y in patients clearing infection after chloroquine treatment in the Sudan. Acta Trop 2006, 97:19-25.

17. Vinayak S, Biswas S, Dev V, Kumar A, Ansari MA, Sharma YD: Prevalence of the K76T mutation in the pfcrt gene of Plasmodium falciparum among chloroquine responders in India. Acta Trop 2003, 87:287-293.

18. Mita T, Kaneko A, Hombhanje F, Hwaihwanje I, Takahashi N, Osawa H, Tsukahara T, Masta A, Lum JK, Kobayakawa T, et al: Role of pfmdr1 mutations on chloroquine resistance in Plasmodium falciparum isolates with pfcrt K76T from Papua New Guinea. Acta Trop 2006, 98:137-144.

19. Ranjit MR, Das A, Chhotray GP, Roth RN, Kar SK: The PfCRT (K76T) point mutation in Plasmodium falciparum, and its usefulness for monitoring chloroquine resistance. Ann Trop Med Parasitol 2004, 98:879-882.

20. Vathsala PG, Pramanik A, Dhanasekaran S, Devi CU, Pillai CR, Subbarao SK, Ghosh SK, Tiwari SN, Sathyanarayan TS, Deshpande PR, et al: Widespread occurrence of the Plasmodium falciparum chloroquine resistance transporter (Pfcrt) gene haplotype SVMNT in P. falciparum malaria in India. Am J Trop Med Hyg 2004, 70:256-259.

21. Wele M, Djimde AA, Guindo A, Beavogui AH, Traore IZ, Sadou A, Blaise D, Diallo DA, Wellems TE, Doumbo OK: High frequency of PfCRT 76T in two Malian villages and its prevalence in severe relative to non-severe malaria. Acta Trop 2011.

22. Daily JP, Roberts C, Thomas SM, Ndir O, Dieng T, Mboup S, Wirth DF: Prevalence of Plasmodium falciparum pfert polymorphisms and in vitro chloroquine sensitivity in Senegal. Parasitology 2003, 126:401-405.

23. Ochong EO, van den Broek IV, Keus K, Nzila A: Short report: association between chloroquine and amodiaquine resistance and allelic variation in the Plasmodium falciparum multiple drug resistance 1 gene and the chloroquine resistance transporter gene in isolates from the upper Nile in southern Sudan. Am J Trop Med Hyg 2003, 69:184-187.

24. Alkadi HO, Al-Maktari MT, Nooman MA: Chloroquine-resistant Plasmodium falciparum local strain in Taiz Governorate, Republic of Yemen. Chemotherapy 2006, 52:166-170.

25. Al-Maktari MT, Bassiouny HK: Malaria status in Al-Hodeidah Governorate, Republic of Yemen. Part II: Human factors causing the persistence of chloroquine resistant P. falciparum local strain. J Egypt Soc Parasitol 2003, 33:829-839.

26. Bassiouny HK, Al-Maktari MT: Malaria in late pregnancy in Al Hodeidah Governorate, Yemen. East Mediterr Health J 2005, 11:606-617.

27. Al-Taiar A, Jaffar S, Assabri A, Al-Habori M, Azazy A, Al-Mahdi N, Ameen K, Greenwood BM, Whitty CJ: Severe malaria in children in Yemen: two site observational study. BMJ 2006, 333:827.

28. Al-Mekhlafi AM, Mahdy MA, A AA, Fong MY: Molecular epidemiology of Plasmodium species prevalent in Yemen based on $18 \mathrm{~s}$ rRNA. Parasit Vectors 3:110.

29. Al-Mekhlafi A, Mahdy M, Azazy A, Fong M: Clinical situation of endemic malaria in Yemen. Tropical Biomedicine 2010, 27:551-558.

30. Al-Shamahy H, Al-Harazy AH, Harmal NS, Al-Kabsi AM: The prevalence and degree of resistance of Plasmodium falciparum to first-line antimalarial drugs: an in vitro study from a malaria endemic region in Yemen. Ann Saudi Med 2007, 27:432-436.

31. NMCP: Malaria Report. Book Malaria Report City: National Malaria Control Programme; 2002.

32. Bin Mohanna MA, Bin Ghouth AS, Rajaa YA: Malaria signs and infection rate among asymptomatic schoolchildren in Hajr Valley, Yemen. East Mediterr Health I 2007, 13:35-40.

33. Al-Mekhlafi AM, Mahdy MA, Azazy AA, Fong MY: Molecular epidemiology of Plasmodium species prevalent in Yemen based on 18s rRNA. Parasit Vectors 2010, 3:110

34. Tinto H, Ouedraogo JB, Erhart A, Van Overmeir C, Dujardin JC, Van Marck E, Guiguemde TR, D'Alessandro U: Relationship between the Pfcrt T76 and the Pfmdr-1 Y86 mutations in Plasmodium falciparum and in vitro/in vivo chloroquine resistance in Burkina Faso, West Africa. Infect Genet Evol 2003, 3:287-292

35. Azazy AA, Raja'a YA: Malaria and intestinal parasitosis among children presenting to the paediatric centre in Sana'a, Yemen. East Mediterr Health J 2003, 9:1048-1053.

36. Giha HA, Elbashir MI, IE AE, TM AE, ElGhazali GE, Mackinnon MJ, Babiker HA: Drug resistance-virulence relationship in Plasmodium falciparum causing severe malaria in an area of seasonal and unstable transmission. Acta Trop 2006, 97:181-187.

37. Mayengue PI, Kalmbach Y, Issifou S, Kremsner PG, Ntoumi F: No variation in the prevalence of point mutations in the Pfcrt and Pfmdr1 genes in isolates from Gabonese patients with uncomplicated or severe Plasmodium falciparum malaria. Parasitol Res 2007, 100:487-493.

38. Ranjit MR, Das A, Chhotray GP, Das BP, Das BN, Acharya AS: The PfCRT (K76T) point mutation favours clone multiplicity and disease severity in Plasmodium falciparum infection. Trop Med Int Health 2004, 9:857-861.

39. Chuma JM, Thiede M, Molyneux CS: Rethinking the economic costs of malaria at the household level: evidence from applying a new analytical framework in rural Kenya. Malar J 2006, 5:76

40. Hustache S, Nacher M, Djossou F, Carme B: Malaria risk factors in Amerindian children in French Guiana. Am J Trop Med Hyg 2007, 76:619-625.

41. Al-Taiar A, Assabri A, Al-Habori M, Azazy A, Algabri A, Alganadi M, Whitty CJ, Jaffar S: Socioeconomic and environmental factors important for acquiring non-severe malaria in children in Yemen: a case-control study. Trans R Soc Trop Med Hyg 2009, 103:72-78

42. Kang JM, Moon SU, Kim JY, Cho SH, Lin K, Sohn WM, Kim TS, Na BK: Genetic polymorphism of merozoite surface protein-1 and merozoite surface protein-2 in Plasmodium falciparum field isolates from Myanmar. Malar J 2010, 9:131.

doi:10.1186/1756-3305-4-94

Cite this article as: Al-Mekhlafi et al:: High frequency of Plasmodium falciparum chloroquine resistance marker (pfcrt T76 mutation) in Yemen: An urgent need to re-examine malaria drug policy. Parasites \& Vectors 2011 4:94. 